\title{
Eosinophilic Pneumonia Due to Toxocariasis: An Adult Case Report
}

\author{
Erişkin Bir Hastada Toxocariasis’e Bağlı Eozinofilik Pnömoni Olgusu
}

\author{
Mustafa Demirci', Mehmet Ünlü², Fatma Fidan², Selçuk Kaya³
}

'Department of Medical Microbiology, Faculty of Medicine, İzmir Katip Çelebi University, İzmir, Turkey

2Department of Chest Diseases, Faculty of Medicine, Afyon Kocatepe University, İstanbul, Turkey

${ }^{3}$ Department of Medical Microbiology, Faculty of Medicine, Süleyman Demirel University, Isparta, Turkey

\begin{abstract}
Toxocara is a roundworm, a common parasite of dogs (T. canis) and cats (T. cati). Toxocariasis or Visceral larva migrans (VLM) are diseases caused by the larvae of Toxocara sp., which may involve many organs, but pulmonary symptoms such as coughing and wheezing and allergic symptoms are seen in more than $80 \%$ of patients. It is known that, although the risk of infection is present, the worldwide diagnosis of toxocariasis is difficult since clinical and laboratory data provide insufficient evidence for the diagnosis. Nowadays, the diagnosis of toxocariasis is performed by serologic methods. We describe herein a case of toxocariasis with eosinophilic pneumonia that was diagnosed using serologic methods. (Turkiye Parazitol Derg 2012; 36: 258-9)
\end{abstract}

Key Words: Toxocariasis, eosinophilia, pneumonia

Received: 12.08 .2012

Accepted: 09.11.2012

\section{ÖZET}

Toxocariasis veya visseral larva migrans, birçok organ tutulumuyla birlikte olguların \% 80 'inde alerjik akciğer semtomların geliştiği, dünyada yaygın olarak kedi ve köpeklerin paraziti olan Toxocara canis veya T. cati larvalarının neden olduğu hastalıktır. Dünyada hastalık riskinin yaygın bulunmasına karşın, klinik ve laboratuvar verilerinin hastalığın tanısında zaman zaman yetersiz kalmaktadır. Günümüzde, toxocariasis tanısı geliştirilen serolojik metodlar sağlanmaktadır. Burada eozinofilik pnömoni gelişen ve serolojik metotlar ile toxocariasis tanısı konulan bir olgu sunulmuştur. (Turkiye Parazitol Derg 2012; 36: 258-9)

Anahtar Sözcükler: Toxocariasis, eozinofilia, pnömoni

Geliş Tarihi: 12.08.2012

Kabul Tarihi: 09.11.2012

\section{INTRODUCTION}

Human infection with toxocariasis occurs following ingestion of embryonated eggs from the environment. The larvae penetrate the gut wall and begin a migration through the tissues. This can continue for several years. Sero-prevalence studies suggest that schoolchildren are infected more often than adults. Most disorders consequent to Toxocara infection are due to the damage caused by an inflammatory immune response. Infected subjects often are asymptomatic, but infected children may display cough, fever, abdominal pain, hepatomegaly, and skin lesions.
Severe infections are rare but may cause respiratory distress or myocarditis $(1,2)$. Blood hyper-eosinophilia, which is a frequent sign of tissue invasion by parasites, is inconstant in toxocariasis, and the most reliable diagnostic method is an ELISA which has 98\% specificity, since larvae are hardly ever found upon pathological examination $(3,4)$.

\section{CASE REPORT}

The patient is a 52 year-old male with no other significant characteristics except diabetes mellitus, which was controlled by an oral agent for the previous 3 years, and a his-

Address for Correspondence / Yazışma Adresi: Dr. Mustafa Demirci, Department of Medical Microbiology, Faculty of Medicine, İzmir Katip Çelebi University, Izmir, Turkey Phone: +90 5064721298 E-mail: demircidr@hotmail.com doi:10.5152/tpd.2012.61 
tory of cigarette smoking (20 packs per year). The patient was admitted to the outpatient clinic with complaints of malaise, dyspnoea, purulent discharge of sputum and a cough. He had experienced these symptoms for 10 days and a bilateral broncho-pneumonic appearance was present in the middle and lower zones of the chest $x$-ray, therefore he was hospitalised. In the physical examination, blood pressure was $120 / 80 \mathrm{mmHg}$, pulse was $92 / \mathrm{min}$ and body temperature was $37.3^{\circ} \mathrm{C}$. The respiratory sounds were bilaterally similar and he had bilateral fine rales and an expiratory rhonchus. All other systemic observations were normal. Laboratory investigations were as follows: leukocytes $13970 / \mathrm{mm}^{3}$, eosinophil $3160 / \mathrm{mm}^{3}$ (22.6\%), sedimentation rate $73 \mathrm{~mm} / \mathrm{hr}$, and gamma glutamyl transferase (GGT) $204 \mathrm{U} / \mathrm{L}$. The rest of the routine blood analyses and urine analyses were within the normal limits. Moderate obstruction was detected with the pulmonary function tests. No colonisation was present in the sputum culture and direct microscopy for tuberculosis was negative. Abdomen USG was normal. Endo-bronchial appearance was normal on bronchoscopy. Broncho-alveolar lavage (BAL) was performed through the superior segment of the lower lobe of the right lung. BAL cell ratios were as follows: macrophage $46 \%$, eosinophils $42 \%$, lymphocytes $8 \%$, and neutrophils $4 \%$. Cytological analysis of BAL fluid did not reveal any neoplastic cells. Microbiological investigations for bacteria, mycobacteria, and fungi were negative. In the computerised tomography of the thorax, an appearance reminiscent of pneumonic infiltration was present in the superior lobe, posterior segment of the right lung and the superior segments of the lower lobes of the right and left lungs. Parasitic analyses of the faecal specimen, sputum, and BAL were negative. IgE level was $2034 \mathrm{u} / \mathrm{mL}$ following the serological tests performed in order to detect a parasitic disease (toxocariasis, fasciolosis, and cystic echinococcosis). Toxocara serology was positive by ELISA method (The ELISA absorbance value was 2.760). Later, a positive Toxocara specific IgE value was determined also using the same homemade ELISA method.

With these findings, the case was diagnosed as a case of Eosinophilic pneumonia due to toxocariasis; prednisolone 0.75 $\mathrm{mg} / \mathrm{kg} /$ day and albendazole $15 \mathrm{mg} / \mathrm{kg} /$ day was added to the bronchodilator agent the patient had been using. On the third day of the treatment, the pathological physical signs of the patient were diminished, his dyspnoea disappeared and radiological regression was observed with the chest x-ray. In the control after six month, eosinophilia was decreased to a level of 340/ $\mathrm{mm}^{3}$ (2.6\%), sedimentation was normal and GGT level was decreased to $87 \mathrm{u} / \mathrm{mL}$.

\section{DISCUSSION}

Clinical manifestations of toxocariasis or visceral larva migrans (VLM) are the result of allergic and inflammatory responses of the host, and manifest as airway reactivity, acute pneumonia, and persistent eosinophilia. VLM is a self-limiting disease and specific treatment is rarely necessary. In acute cases, a short course of steroids reduces morbidity and mortality, but preventive measures are more important in curbing Toxocara infection $(1,2)$. In our patient, intravenous corticosteroid therapy produced a rapid improvement in the clinical picture. Pulmonary infiltration resolved within 10 days after the start of treatment.

Schinkewitch et al. (5) reported a case of bilateral eosinophilic pneumonia in a 33 year-old man due to T. canis, and the ELISA index was strongly positive at 2.597. The patient developed a rapidly progressive respiratory failure requiring mechanical ventilation. Intravenous corticosteroid therapy produced a rapid improvement. Roig et al. (6) reported diffuse pulmonary infiltration and $64 \%$ eosinophilia in the BAL fluid in a toxocariasis patient who had dyspnoea. They suggested that the routine performance of the ELISA test for Toxocara in the diagnostic approach to pulmonary infiltration with eosinophilia can reveal an undetermined, sometimes unsuspected, number of cases of adult toxocariasis with pulmonary involvement. Bouchard et al. (7) reported a case of acute severe eosinophilic pneumonia the existence of positive $T$. canis serology whose outcome was rapidly favourable following steroid therapy.

Although toxocariasis is a frequent disease in children, the severe clinical manifestations are rarely reported in the literature (diffuse interstitial pneumonia with hypoxaemia and acute severe asthma). In adults, toxocariasis is unusual and infections appear to be mild or subclinical, provoking positive serological tests and sometimes, persistent eosinophilia (occult toxocariasis). Eosinophilic pneumonia seems to be rare in adults with toxocariasis, but there are eosinophilic syndromes that do not have a determined aetiological agent in the literature. However, as described in this case report, this aetiology should be kept in mind when dealing with a case of eosinophilic pneumonia in adults, and serological diagnosis should be considered. Although parasite examination in stool samples has been widely carried out in patients with eosinophilia, tissue parasites are paid insufficient attention in diagnosis (3).

\section{CONCLUSION}

The present case established that ELISA for toxocariasis can remove the difficulty of the diagnosis of toxocariasis. If serological methods use routine diagnosis, physicians must understand the advantages of serological diagnosis in the diagnosis of parasitic diseases and the ability of the laboratory performing them as standard.

\section{Conflict of Interest}

No conflict of interest was declared by the authors.

\section{REFERENCES}

1. Nash TE. Visceral larva migrans and other unusual helminth infections. In: Mandell GL, Bennett JE, Dolin R, editors. Principles and Practice of Infectious Diseases. 5th ed. New York: Churchill Livingstone; 2000.pp.2965-7.

2. Chitkara RK, Sarinas PS. Dirofilaria, visceral larva migrans, and tropical pulmonary eosinophilia. Semin Respir Infect 1997; 12: 138-48.

3. Demirci M, Korkmaz M, Sakru N, Kaya S, Kuman A. Diagnostic importance of serological methods and eosinophilia in tissue parasites. J Health Popul Nutr 2002; 20: 352-5.

4. Glickman L, Schantz P, Dombroske R, Cypess R. Evaluation of serodiagnostic tests for visceral larva migrans. Am J Trop Med Hyg 1978; 27: 492-8

5. Schinkewitch P, Kessler R, Candolfi E, Weitzenblum E. Acute respiratory insufficiency in parasitic eosinophilic pneumonia. Rev Mal Respir 1997; 14: 61-3.

6. Roig J, Romeu J, Riera C, Texido A, Domingo C, Morera J. Acute eosinophilic pneumonia due totoxocariasis with broncho-alveolar lavage findings. Chest 1992; 102: 294-6. [CrossRef]

7. Bouchard O, Arbib F, Paramelle B, Brambilla C. [Acute eosinophilic pneumonia and the larva migrans syndrome: apropos of a case in an adult] Rev Mal Respir 1994; 11: 593-5. 